\title{
PENERAPAN DAN PEMBAHARUAN HUKUM ISLAM \\ DALAM TATA HUKUM TURKI
}

\author{
Jaenudin \\ Fakultas Syari'ah dan Hukum UIN Sunan Gunung Djati Bandung \\ Jl. A. H. Nasution Nomor 105 Bandung \\ Email: jaenudin67@yahoo.co.id
}

\begin{abstract}
Abstrak
Turki adalah sebuah negara modern yang bertransformasi Daulah Utsmaniyah. Sebagai sebuah negara modern, Turki dalam penerapan hukum tidak bisa lepas dari sistem Islam, akan tetapi juga telah banyak berubah sejak mulai diterapkannya sistem sekular. Sistem sekular diterapkan di Turki seiring dengan dihapuskannya sistem khilafah tahun 1924. Sejak itu Turki berubah menjadi negara modern dengan tampilan sekular. Akan tetapi hukum Islam di Turki tidak dapat dilepaskan seiring dengan perjalanan panjang Daulah Utsamniyah yang di antaranya adalah lahirnya majalah ahkam adliyah sebagai salah satu produk hukum Turki Utsmani.
\end{abstract}

\section{Kata Kunci:}

Hukum Islam, Majalah Ahkam Adliyah, dan Turki

\section{A. Pendahuluan}

Semenjak abad kesembilan belas, tumbuh kontak yang semakin akrab antara peradaban Islam dan peradaban Barat. Kontak peradaban ini, menghadapkan Islam pada situasi yang sungguh berbeda. Secara politis, sosial dan ekonomi, peradaban Barat berlandaskan pada konsepkonsep dan lembaga-lembaga yang asing untuk tradisi Islam. Ketika tradisi Islam dalam kekakuan serta dominannya teori taqlid (kesetiaan yang ketat terhadap doktrin yang sudah mapan), maka kemudian lahir pertentangan yang tidak dapat dipertemukan antara hukum tradisional (Islam) dan kebutuhan masyarakat Muslim, yang kemudian melahirkan upaya meniru dan menciptakan patokan-patokan dan nilai-nilai yang berdasarkan cara Barat. Akibatnya yang muncul kemudian adalah 
bahwa tidak ada pilihan lain kecuali mengesampingkan Syari'ah, dan menggantikan-nya dengan hukum yang diilhami dari Barat. ${ }^{1}$

Kondisi inilah yang dialami Turki Utsmani (sekarang Republik Turki). Turki yang merupakan sebuah negara besar, secara geografis berada di dua kawasan, setengah berada di Asia dan setengahnya lagi berada di daratan Eropa, dan secara kultur Turki merupakan pertemuan antara Islam dan juga Eropa (Barat), sedang mengalami kemundurankemuduran baik secara politik, sosial, budaya maupun hukum. Kondisi ini kemudian mendorong terjadinya upaya reformasi Turki Utsmani yang bertahap yang kemudian mengarah kepada pendekatan radikal terhadap upaya modernisasi (lebih tepatnya westernisasi) Turki, yang belum pernah dilakukan oleh negeri Islam manapun, yang salah aspeknya adalah modernisasi dalam tata hukum Turki.

Sejarah Turki moderen tidak bisa lepas dari sejarah Dinasti Turki Utsmani atau Turki Ottoman yang muncul pada abad ke-13. Para pendiri dinasti ini adalah bangsa Turki dari kabilah Oghuz yang mendiami daerah Mongol dan daerah utara negeri Cina. ${ }^{2}$ Di bawah tekanan serbuan bangsa Mongol, pada abad ke-13 orang-orang Turki melarikan diri ke arah barat dan akhirnya mencari tempat pengungsian di tengah saudara-saudara mereka, orang-orang Turki Seljuk, di dataran tinggi Asia Kecil. Sebagian besar populasi daerah ini merupakan orang-orang Turki yang memeluk Islam, dan sebagiannya lagi terdiri atas orang Yunani, Yahudi dan Armenia. ${ }^{3}$

Kepemimpinan Ertugrul (w. 1280) beralih kepada putranya yang bernama Usman, yang menjadi tokoh besar. Di mana nama dinasti "Utsmani" berasal dari nama Usman, putra Ertugrul, sebagai pendiri dinasti Utsmani. Usman memerintah antara tahun 1290-1326. Sebagaimana ayahnya, Usman banyak berjasa kepada Sultan Alauddin II yang berhasil menduduki benteng-benteng Bizantium yang berdekatan dengan kota Broessa. Pada tahun 1300, bangsa Mongol menyerang kerajaan Seljuk dan Sultan Alauddin terbunuh. Kerajaan Seljuk Rum ini kemudian terpecah-pecah dalam beberapa kerajaan keil. Kemudian, Usman menyatakan kemerdekaannya dan berkuasa penuh atas daerah

1 Noel J. Coulson, Hukum Islam dalam Perspektif Sejarah, terj. Hamid Ahmad, (Jakarta: P3M. 1987), hlm. 175.

2 Badri Yatim, Sejarah Peradaban Islam (Jakarta: PT. RajaGrafindo Persada. 2001), hlm. 129.

3 Hassan Ibrahim Hassan, Sejarah dan Kebudayaan Islam (Yogyakarta: Kota Kembang. 1997), hlm. 324. 
Jaenudin: Penerapan dan Pembaharuan Hukum Islam dalam Tata Hukum Turki | 21

yang dikuasinya. ${ }^{4}$ Sejak itulah kerajaan Utsmani berdiri, dengan rajanya Usman atau Utsmani.

Wilayah kekuasaan Dinasti Utsmani terus berkembang mulai dari wilayah Balkan, Yunani Utara, Mecodonia, dan Bulgaria. Setelah memantapkan landasan imperium di Eropa, mereka kemudian melancarkan upaya pencaplokan beberapa wilayah kesultanan Turki Seljuk yang menjadi sainganannya di Anatolia Barat dan mempersiapkan bagi penyerbuan ke Konstantinopel.

Upaya ekspansi Utsmani ke Konstantinopel terhenti, ketika muncul tentara Mongol yang dipimpin Timur Lenk melakukan serangan ke Asia Kecil. Pada tahun 1402, tentara Turki mengalami kekalahan di tangan Timur Lenk. Bayazid bersama putranya Musa tertawan, dan wafat dalam tawanan tahun 1403. Kekalahan Bayazid membawa akibat buruk bagi negara besar Utsmani. Penguasa-penguasa Seljuk di Asia Kecil melepaskan diri dari genggaman Turki Utsmani. Wilayah Serbia dan Bulgaria menarik diri dari kekuasaan Utsmani. ${ }^{5}$

Kejayaan Turki Utsmani naik kembali pada masa Muhammad II atau disebut juga Muhammad Al-Fatih (1451-1484), dengan menaklukkan konstantinopel pada tahun 1453, sebagai sisa terakhir negara besar Bizantium. Secara keseluruhan Wilayah Turki Utsmani, terutama era Sultan Sulaiman Al-Qanuni meliputi Asia Kecil, Armenia, Irak, Syria, Hijaz, Yaman di Asia; Mesir, Libia, Tunis, Aljazair di Afrika; Bulgaria, Yunani, Yugaslavia, Albania, Hongaria, dan Rumania di Eropa. ${ }^{6}$

Melihat luasnya imperium Utsmani, Ira M. Lapidus ${ }^{7}$ menjelaskan, "Turki Utsmani telah menciptakan sebuah imperium berskala dunia yang terbentang dari wilayah barat laut Tengah sampai Iran, dari Ukraina sampai ke Yaman. Dinamisme yang mendorong ekspansi pemerintah Utsmani yang berskala dunia ini, berasal dari karakteristik bangsa Turki dan masyarakat utsmani. Tujuan dari serangkaian perang suci yang dilakukan Utsmani adalah membentuk sebuah negara imperial yang kapasitas organisasional-nya sangat istimewa".

Dinasti Utsmani merupakan salah satu kekhalifahan Islam yang mampu memiliki wilayah yang sangat luas, yang bertahan selama

\footnotetext{
4 Badri Yatim, Sejarah Peradaban Islam. hlm. 130.

5 Ibid., hlm. 131.

6 Ibid., hlm. 132.

${ }^{7}$ Ira M. Lapidus, Sejarah Sosial Ummat Islam (Jakarta: PT. RajaGrafindo Persada.
} 2000), jilid 1-2, hlm. 486. 
kurang lebih delapan abad (1281-1924), yang kemudian kekuasaan Utsmani digantikan dengan negara Republik Turki modern yang dideklarasikan pada Oktober 1923.

Perubahan dari Kesulltanan Utsmani ke Negara Republik tidak lepas dari gerakan pembaharuan yang dilakukan pada masa Tanzimat. Tanzimat (berarti mengatur, menyusun dan memperbaiki) merupakan bahasa Turki, menunjukkan suatu periode reformasi sosial dan politik yang mengubah Kesultanan Utsmani dengan mengintegrasikan ke dalamnya lembaga-lembaga yang secara sengaja dijiplak dari Eropa Barat.

Asal usul Tanzimat terletak pada paro kedua abad ke-18 ketika berlangsung upaya berkelanjutan untuk memodernisasi kesultanan Turki Utsmani, yang pada mulanya mencari modus vivendi untuk kerajaan Utsmani dengan meminjam ide-ide dan teknik Barat. Modernisasi Turki hampir bersamaan dengan di Rusia, tetapi pola dari proses ini berbeda di kedua negeri tersebut. Di Rusia, Peter Agung membawa perubahan-perubahan Barat secara berurutan, hingga rakyatnya yang terbelakang itu dapat dimungkinkan maju bersama-sama dengan bangsa-bangsa Eropa. Adapun di Turki, Sultan Salim III (1798-1807) dan pengganti-penggantinya melaksanakan pembaruan-pebaruan Barat untuk memberikan nafas baru kepada kehidupan imperium Utsmani yang sedang dalam proses mundur. ${ }^{8}$ Aspek terpenting dari upaya ini adalah memodernisasi militer, khususnya pendirian sekolah teknik kemiliteran. Dan kecenderungan di antara elit birokrasi untuk meniru hidup kelas atas di Barat. Penerjemahan teks-teks ilmiah Barat di bidang kedokteran, botani, astronomi, dan matematika berlangsung sepanjang sisa abad itu. Seiring dengan meningkatnya penghargaan terhadap aspek-aspek material budaya Barat, muncul ketertarikan di kalangan elit terhadap terhadap hal-hal yang disebut sebagai masyarakat sipil Barat. ${ }^{9}$

Pembaruan ala Barat yang dilakukan oleh Sultan Salim III pada umumnya terkenal dengan istilah Nizam-i Cedid (orde baru) merupakan usaha pertama yang luas untuk pembaratan. Namun usaha sultan ini tidak memperoleh dukungan dari ulama yang bersama-sama dengan hlm. 9.

8 Mukti Ali, Islam dan Sekularisasi di Turki Modern (Jakarta: Djambatan. 1994),

9 Serip Mardin, "Tanzimat", dalam John L. Esposito (ed.), Ensiklopedi Oxford Dunia Islam Modern, terj. Eva Y.N. dkk. (Bandung: Mizan, 2001), jilid 5, hlm. 345. 
Jannisari menentang pembaruan itu, dan Syari'ah tetap merupakan hukum yang tertinggi bagi Imperium Utsmani. ${ }^{10}$

Pada tahun 1837, Sultan Mahmud II (mem. 1808-1839) atas usulan para anggota dewannya mendirikan dua badan baru: Dewan Menteri (Dâr-i surâ-yi Bâb-i Âli) dan Dewan Ordinansi Hukum Pengadilan (Meclis-i Vâlâ-yi Ahkam-i Adliye). Evolusi dari badan-badan ini sepanjang abad ke-19, pada akhirnya mengarah kepada pemisahan kekuasaan eksekutif dari yudikatif. Tahun 1839, Sultan Abdul Majid (mem. 1839-1861), yang menggantikan Sultan Mahmud II, mengeluarkan Hatt-i Syerif Gulhane (Piagam Gulhane), atas gagasan Mustafa Rasyid Pasha, yang menjabat Perdana menteri Turki Utsmani dan tokoh Tanzimat. 11

Piagam Gulhane menjelaskan tentang perubahan-perubahan yang harus dilakukan oleh pemerintah yaitu, (1) Terjaminnya ketenteraman hidup, harta dan kehormatan warga negara; (2) Peraturan mengenai pemungutan pajak; (3) Peraturan mengenai kewajiban dan lamanya dinas militer; dan (4) Persamaan dalam hukum, tanpa memandang perbedaan agama. ${ }^{12}$

Pada tahun 1856, pemerintah Turki Utsmani mengeluarkan dokumen penting kedua dari program Tanzimat, yaitu Maklumat Reformasi (Islâhat Fermani) atau Piagam Humayun (Hatt-i Humayun), yang memperkuat jaminan-jaminan yang tercantum dalam Piagam Gulhane. Piagam ini diadakan atas desakan negara-negara Eropa pada kerajaan Turki Utsmani yang pada waktu itu dalam keadaan lemah dan selalu mengalami kekalahan dalam peperangan. Negara-negara Eropa mau menjamin keutuhan Kerajaan Utsmani, kalau kerajaan Utsmani bersedia memberi lebih banyak hak-hak yang sama kepada rakyatnya yang bukan beragama Islam dan bukan berasal dari Turki, terutama bangsa Eropa. Dokumen ini menjamin bahwa Muslim dan non-Muslim memiliki hak dan kewajiban yang sama di depan hukum dalam hal keterlibatan dalam militer, administrasi hukum, pajak, penerimaan di lembaga pendidikan, serta pekerjaan di sektor publik.

Proses pembaruan Tanzimat berakhir tahun 1877, ketika Sultan Abdul Hamid II (1876-1909), menangguhkan Konstitusi baru Turki Utsmani yang terbentuk tahun 1976 dan memecat Mithat Pasha,

10 Mukti Ali, Islam dan Sekularisasi. hlm. 13.

11 Harun Nasution, Pembaharuan dalam Islam Sejarah Pemikiran dan Gerakan (Jakarta: Bulan Bintang. 1996), hlm. 99.

12 Ibid., hlm. 100. Lihat juga Erik J. Jurcher, Turkey A Modern History (London: I. B. Tauris. 1995), hlm. 53. 
pengagas Konstitusi dan Perdana Menteri Turki Utsmani saat itu. Kendati reformasi Tanzimat terhenti, modernisasi Turki terus berjalan di bawah gerakan Turki Muda (1908-1918) --dipimpin Said Halim Pasha, yang Islamis dan Ziya Golap, yang Nasionalis--, dan Republik Turki (1923) --di bawah Mustafa Kemal Attaturk.13

Setelah pembubaran kesultanan Utsmani pada 1922, kaum Kemalis bermain-main dengan gagasan untuk mempertahankan khalifah sebagai seorang pemimpin simbolis. Namun, ambisi khalifah Abdul Majid, yang didukung oleh lawan-lawan politik Mustafa Kemal, memaksa pemerintah untuk bertindak cepat dan membubarkan kekhalifahan pada tanggal 3 Maret 1924. Dari tahun 1925-1929, kaum Kemalis mempergunakan masa waktu tersebut untuk memunculkan sebuah program pembaruan yang secara efektif menyisihkan Islam dari kehidupan politik dan menjadikan masyarakat sekular, gerakan ini lebih dikenal sebagai sekularisasi Turki.

Pada tahun 1925, kelompok tarekat sufi dan makam-makam suci ditutup, penyembuhan dengan tiupan napas oleh para syaikh, baba, seyyid, mursyid, dede, dan celebi pun menjadi terlarang. Pemakaian fez, sebuah simbol identitas Muslim, dipandang melanggar hukum, dan kaum laki-laki diwajibkan mengenakan topi. Kalender Gregorian diambil bersama-sama dengan jam dinding 24 jam. Tahun 1926, hukum sipil Swiss menggantikan hukum Syariat, sehingga memisahkan para ulama dari sumber pengaruh tradisional mereka. Kemudian tahun 1928, Majelis memutuskan untuk menghilangkan kalimat "Agama negara Turki adalah Islam" dari pasal 2 konstitusi negara, menuntaskan penyingkiran Islam. ${ }^{14}$

Puncak dari liberalisasi Turki terjadi pada tahun 1932, di mana Islam secara politik dan kultur "dinasionalisasikan"; Al-Quran dibaca dalam bahasa Turki, di susul azan berbahasa Turki pada Tahun 1933, dan azan kembali dalam bahasa Arab pada tahun 1950. Menurut Feroz Ahmad, "Tujuan pembaruan radikal ini bukanlah anti-Islam, tetapi politis: memisahkan seluruh lembaga hukum, sosial, dan kependidikan dari yuridiksi para pemimpin agama berserta sekutu-sekutu politik mereka serta meletakannya ke tangan Direktrorat Urusan Agama. Dengan demikian, negara dapat mengarahkan energi keagamaan menuju program sosial-ekonominya sendiri". 15

13 Mardin, "Tanzimat”, dalam John L. Esposito. hlm. 348.

${ }_{14}$ Feroz Ahmad, "Turki", dalam John L. Esposito (ed.), Ensiklopedi Oxford Dunia Islam Modern, terj. Eva Y.N. dkk. (Bandung: Mizan, 2001), jilid 6, hlm. 64.

15 Ibid., hlm. 65. 
Jaenudin: Penerapan dan Pembaharuan Hukum Islam dalam Tata Hukum Turki | 25

\section{B. Syariat dan Reformasi Hukum di Turki}

Sebagai sebuah negara muslim, Turki memiliki sejarah panjang baik dalam politik maupun hukum. Kekuasaan sebelumnya, Kekhalifahan Turki Utsmani merupakan salah satu kekuatan dari tiga kekuatan dunia Islam pada saat itu yang berhaluan sunni, di samping kerajaan Safawi di Persia yang berfaham syiah dan kerajaan Moghul yang juga masih sunni.

Pemerintah Turki Utsmani pada umumnya menganut madzhab Hanafi, salah satu dari empat madzhab madzhab sunni yang terkemuka. ${ }^{16}$ Pengaruh mazhab Hanafi tidak hanya pada masa pemerintahan Turki Utsmani, tetapi juga sangat berpengaruh pada masa kekhalifahan Abbasiyah, di mana salah satu murid Imam Abu Hanifa, Ya'qub ibn Ibrahim Al-Anshari yang lebih dikenal dengan nama Abu Yusuf (731798) pernah diangkat pada Dinasti Abbasiyah sebagai hakim di Bagdad dan kemudian menjadi qâdhî al-qudhât (hakim kepala) dengan wewenang mengangkat hakim-hakim kekhalifahan. Salah satu karya Abu Yusuf, Kitâb Al-Kharâj, disusun untuk Khalifah Harun Al-Rasyid.

Kini mazhab Hanafi masih merupakan mazhab resmi yang berwenang mengeluarkan fatwa dan diterapkan pada status personal kaum Muslim Sunni di negara-negara pelanjut Kesultanan Utsmani, seperti Mesir, Suriah, Lebanon, Irak, Yordania, dan Israel-Palestina. Di Turki sendiri, yang resmi sekular, hukum Hanafi mengatur kegiatan-kegiatan ibadah. Mazhab Hanafi juga menjadi mazhab dominan dalam hal statuspersonal, juga dalam kegiatan-kegiatan ibadah di kalangan kaum Muslim di semanjung Balkan, Kaukus, Afganistan, Pakistan, India, Republik-republik di Asia tengah, dan Cina. ${ }^{17}$

16 Mazhab Hanafi merupakan salah satu mazhab hukum yang dinisbatkan kepada Abu Hanifah. Abu Hanifah (699-767), merupakan nama panggilan Nu'man ibn Tsabit, ia keturunan Persia dan penduduk asli Kufah. Dia mula-mula mempelajari ilmu-ilmu skolastik dan kemudian memusatkan diri pada yurisfrudensi mazhab Kufah seraya mencari nafkah sebagai pedagang tekstil. Pendidikannya dalam ilmu-ilmu skolastik digabung dengan pengalamannya sebagai pedagang memberinya kemampuan luar biasa dalam menggunakan nalar dan logika untuk menerapkan kaidah-kaidah pada persoalan-persoalan praktis kehidupan, dan dalam memperluas kaidah-kaidah itu dengan menggunakan analogi (qiyas) dan preferensi (istihsan). Sikap bebasnya yang menggunakan istihsan menyebabkan mazhabnya disebut $A h l A l-R a ' y$. diriwayatkan bahwa dia pernah berkata, "Pengetahuan yang menjadi milik kita ini adalah pendapat; inilah yang terbaik yang dapat kita capai. Mereka yang dapat sampai pada kesimpulan-kesimpulan berbeda, berhak atas pendapatnya, sebagaimana kita berhak atas pendapat kita sendiri". Farhat J. Ziadeh, "Mazhab-Mazhab Hukum Sunni", dalam John L. Esposito (ed.), Ensiklopedi Oxford Dunia Islam Modern, terj. Eva Y.N. dkk. (Bandung: Mizan. 2001), Jilid 2, hlm. 200.

17 Ibid., hlm. 202. 
Pada awal abad ke-16, khususnya masa Salim I (mem. 1512-1520) dan masa Sulaiman I (mem. 1520-1560), seluruh administrasi peradilan Turki Utsmani besumber pada Syari'ah, bahkan mereka menciptakan unit-unit terkecil bagi administrasi sipil yang sama intensifnya dengan qadha. Distrik di mana qadhi berkuasa, mengangkat kepala polisi lokal atas perintah-perintah qadhi. Mereka menyelenggrakan latihan-latihan yang seragam bagi ulama-ulama dan qadhi, mengangkat mereka dengan jabatan yang diatur secara hierarkhi, dan mereka diberi gelar Mufti Agung bagi mufti yang berkedudukan di Istambul, yang secara hierarkhi merupakan jabatan yang tinggi dan digelari Syaikh al-Islâm. Mufti Agung (Syaikh al-Islâm) tersebut bertanggung jawab untuk menjamin terlaksananya hukum suci dalam negara dan berkewajiban memberi petunjuk kepada qadhi. ${ }^{18}$

Jabatan Mufti Agung kemudian mencapai puncaknya pada kekuasaan Sulaiman I, yaitu ketika Abu Su'ud menjabat sebagai Mufti Agung pada tahun 1545-1574. Abu Su'ud berhasil menyesuaikan administrasi hukum pemerintah Utsmani dengan ketentuan Syari'ah. Pada masa Sulaiman I ini pun telah terbentuk sebuah Kanun atau Kanun Name sebagai hukum resmi, ini pula sebabnya Sulaiman I digelari sebagai Sulaiman Al-Qanuni.

Pada awalnya, Kanun ini telah tersusun di bawah pemerintahan Sultan Bayazid II (mem. 1481-1512) di mana konsep-konsep hukum Islam dijadikan sebagai dasar dalam penetapan hukum, tetapi pada masa selanjutnya mengalami perubahan dengan ketentuan-ketenuan baru, seperti hukum Hadd diganti dengan Ta'zir, denda uang ditetapkan berdasarkan kemampuan ekonomi si terhukum. Secara keseluruhan Kanun tersebut berisikan tentang gaji tentara, polisi rakyat yang bukan Muslim, urusan kepolisian dan hukuman, hukum tanah dan hukum perang. Dalam hukum pidana banyak sekali penjelasan tentang hokuman fisik seperti pengebirian, penggantungan bagi yang tidak melaksanakan kewajiban, penggantungan bagi pelaku pemakaran dengan sengaja, pencuri, potong tangan bagi pemalsuan dokumen dan mata uang. Semua hukuman fisik tersebut, diganti dengan denda, atau penyiksaan jika terdapat bukti-bukti yang kuat.19 Menurut Schacht, "Undang-undang kerajaan Utsmani pada abad ke-16 jauh lebih unggul dari undang-undang yang berlaku di Eropa pada masa itu. Kalau tidak

18 Joseph Schacht, Pengantar Hukum Islam, terj. Moh. Said, dkk. Proyek Pembinaan Prasarana dan Sarana PTAI, Dirjen Binbaga Islam, Depag RI, 1985, hlm. 118.

19 Ibid., hlm. 120. 
karena kemunduran yang menimpa imperium tersebut tentulah pengaruhnya akan lain". 20

Perlunya pembaruan di kerajaan Turki untuk pertama kalinya diakui sekitar abad ke-17 ketika kerajaan Utsmani mulai kehilangan kekuatannya. Pembaruan-pembaruan di abad ke-17 itu merupakan upaya-upaya pribumi yang pada umumnya, berpusat di sekitar usaha untuk memperkuat otoritas pemerintah pusat. Namun di awal abad ke18, usaha-usaha pembaruan itu sifatnya lain, sebab kerajaan Utsmani mulai membuka pintu bagi Barat. Kontak-kontak diplomatik dan kultural dengan negara-negara Eropa meyakinkan para negarawan Utsmani akan keunggulan teknik Barat, dan menjadikan mereka berupaya mencari bantuan teknis dalam urusan kemiliteran dari para ahli Barat.

Menjelang akhir abad ke-18, hubungan-hubungan dengan Barat mengakibatkan meningkatnya "pencarian jati diri" karena kaum intelektual dan negarawan Utsmani mulai memandang westernisasi sebagai prasyarat. Karena itu, pada abad ke-19, perhatian pokok para pembaru Utsmani ialah membaratkan angkatan senjata, lembaga-lembaga pendidikan, hukum dan politik kerajaan Utsmani. Namun kemudian muncul problem yang harus dihadapi ialah bagaimana cara melakukan westernisasi dalam suatu masyarakat, di mana Islam sudah berpenetrasi ke dalam sub-kultur sistem sosio-politik Turki Utsmani. Dilema ini memang jelas. Di satu pihak sejumlah besar mereka percaya bahwa keselamatan kerajaan terletak pada penerimaan teknologi dan bentukbentuk institusi Barat. Di lain pihak, tidak seorang pun yang dapat menemukan formula mengenai bagaimana caranya teknologi dan institusi-institusi Barat dapat diterapkan pada suatu masyarakat Islam tanpa menerima peradaban Barat itu sendiri. ${ }^{21}$

Usaha reformasi Turki Utsmani ini dimulai pada pemerintahan Sultan Mahmud II (mem. 1808-1839) dengan membangun sistem hukum sekular di samping hukum Syari'at, di mana hukum Syari'at berada di bawah kekuasaan Syaikh Al-Islam, dan hukum sekular di bawah Dewan Perancang Hukum. Keluarnya Piagam Gulhane pada era Tanzimat membawa pembaruan-pembaruan terhadap berbagai institusi kemasyarakatan Kerajaan Utsmani. Dewan Ordinansi Hukum Pengadilan (Meclisi Vâlâ-yi Ahkam-i Adliye), yang dibentuk masa Sultan Mahmud II, diper-

20 Ibid.,

21 Binnaz Toprak, Islam dan Perkembangan Politik di Turki (Yogyakarta: Tiara Wacana Yogya. 1999), hlm. 59-60 
banyak anggotanya dan diberi wewenang untuk membuat undangundang. Kodifikasi hukum dimulai dan berbagai sumber hukum di samping hukum Syari'at, dipakai pula sumber-sumber di luar agama, di antaranya hukum Barat. ${ }^{22}$

Berdasar latar belakang dalam era reformasi Tanzimat ini, perubahan pertama dan yang mendasar adalah pembentukan peradilanperadilan khusus yang bersifat sekular (Mahkamah Nizamiyyah) di di samping Mahkamah Syar'iyyah yang telah ada, serta diberlakukannya norma-norma hukum baru (selain Syari'ah) untuk ditetapkan pada peradilan-peradilan sekular tersebut.

Kesultanan Turki Utsmani kemudian menerapkan Hukum Dagang pada tahun 1850, sebagian adalah terjemahan langsung dari UndangUndang Hukum Dagang Perancis--termasuk ketentuan tentang pembayaran bunga. Hukum Pidana pada tahun 1858, yang merupakan terjemah dari Kode Penal (Hukum Pidana) Perancis. Kemudian Hukum Administrasi Niaga pada tahun 1861, dan Hukum Perdagangan Laut pada tahun 1863, kedua undang-undang ini pun pada hakekatnya mengikuti model hukum Perancis. ${ }^{23}$ Di samping telah dibentuknya undang-undang berdasarkan hukum Barat, kerajaan Utsmani telah mengkodifikasikan pula sebuah hukum berdasarkan Syari'ah, Majallah (Macelle), yang disusun sekitar tahun 1869-1876, berbentuk aturanaturan, priinsip-prinsip yang lebih moderen yang di ambil dari hukum Hanafi. ${ }^{24}$ Di samping Majallah, pada tahun 1917, pemerintah Utsmani pernah mengeluarkan sebuah Undang-Undang tentang Hak-hak Keluarga. Undang-undang ini merupakan kodifikasi yang agak lengkap mengenai hukum perseorangan dan hukum keluarga, kecuali hukum wasiat dan hibah. Undang-undang ini tidak hanya bersumber pada ajaran-ajaran mazhab Hanafi, tetapi juga bersumber pada beberapa ajaran dari mazhab sunni yang lainnya. Undang-undang ini mencakup sejumlah peraturan hukum acara yang di antaranya disertai dengan ancaman hukuman menurut hukum pidana (jinayat), dan juga beberapa bagian khusus yang berlaku bagi orang Yahudi dan Nasrani. Namun

22 Harun Nasutioin, Pembaharuan dalam Islam.

23 J.N.D. Anderson, Hukum Islam di Dunia Moderen, terj. Machnun Husein (Yogyakarta: Tiara Wacana Yogya. 1994, hlm. 24. Lihat juga Coulson, Hukum Islam. hlm. 177.

${ }^{24}$ Anderson, Hukum Islam di Dunia Moderen. 
Undang-undang ini berlaku hanya sebentar saja di Turki sampai digantikan oleh hukum Perdata Swiss. ${ }^{25}$

Walaupun demikian, berlakunya hukum-hukum baru ini dianggap sekedar tambahan, bukan sebagai perlawanan terhadap Syari'ah. Pembaruan-pembaruan yang pertama berbarengan dengan timbulnya perbedaan pendapat mengenai masalah-masalah kontroversial dalam Syari'ah itu, seperti tentang hukuman mati bagi orang murtad (keluar dari agama Islam dan berganti agama lain). Sedangkan masalah saksisaksi bukan Muslim, setelah melewati perjuangan sengit, akhirnya secara resmi dinyatakan dapat memberikan kesaksian dalam setiap perkara di pengadilan yang melibatkan pihak Muslim. Dalam sudut pandang ini, pembaruan yang dilakukan Tanzimat memperkokoh kedudukan peradilan-peradilan sekular, sedangkan peradilan Syari'ah, sejak saat itu dibatasi wewenangnya hanya pada perkara-perkara status anak dan hukum keluarga (dalam pengertian luas). ${ }^{26}$

Peradilan Syari'ah yang sebelumnya berada dalam yuridiksi Syaikh Al-Islam, pada periode konstitusional kedua, 1917, dilepaskan dari Syaikh Al-Islam. Namun tiga tahun kemudian, pada 1920, peradilah Syari'ah diserahkan kembali kepada Syaikh Al-Islam. Terakhir tahun 1924, peradilan Syari'ah dihapuskan oleh Pemerintahan Republik Turki, dan ditempatkan di bawah yuridiksi kementerian Kehakiman dan pemberlakuan undang-undang sekular saja. Akibat mendasar dari perubahan di bidang peradilan, ialah bahwa institusi agama menjadi kehilangan fungsi-fungsi yustisial yang dimiliki sebelumnya. Akibatnya, konsederasi-konsederasi religius tidak lagi berperan dalam proses hukum, bahkan formula religius bagi pengambilan sumpah di pengadilan pun diubah dengan pernyataan kebenaran berdasarkan kehormatan dan kesadaran individu. ${ }^{27}$

Dalam bidang hukum pun tidak lepas dari sekularasi yang dilakukan oleh kaum Kemalis. Di mana hukum yang berasal dari Eropa menjadi bagian pokok dan integral dari sistem hukum Turki. Pada tahun 1926, Turki mengadopsi Undang-undang Perdata Swiss. UndangUndang baru ini secara fundamental berbeda dari peraturan Syari'ah. Perbedaan-perbedaan itu meliputi:

\footnotetext{
25 Ibid., hlm. 30.

26 Ibid., hlm. 25.

27 Binnaz Toprak, Islam dan Perkembangan Politik. hlm. 90-91.
} 
1. Kebebasan individu untuk memilih afiliasi agamanya. Ini bertentangan sekali dengan larangan yang ada sebelumnya, yaitu larangan meninggalkan aqidah Islam;

2. Sekularisasi upacara pernikahan;

3. Pengadopsian prinsip monogami. Dalam Syari'ah, Muslim pria bisa menikahi sampai empat orang istri;

4. Sekularisasi dalam pelaksanaan penceraian. Dalam Syari'ah, hak talak hampir secara ekslusif berada di tangan pria. Undang-undang baru memberikan hak yang sama kepada kedua belah pihak untuk menuntut talak;

5. Dalam Syari'ah, sementara pria Muslim bisa menikahi wanita nonMuslim, wanita Muslim dilarang melakukan kawin campur. Undang-undang perdata baru menghapuskan larangan ini;

6. Sebagai orang tua, pria maupun wanita (suami atau istri) mempunyai hak yang sama atas anak-anak mereka;

7. Pria dan wanita diberi hak warisan yang sama. ${ }^{28}$

Sementara itu, tahun 1926 Hukum Pidana diambil berasarkan hukum Itali, sedangkan Undang-Undang Hukum Acara Pidana yang menyusul dua tahun kemudian (1928) banyak dipengaruhi oleh hukum Jerman.

Reformasi sekularisasi yang dilakukan oleh Attaturk merupakan reformasi yang paling berani dikawasan ini. Attaturk telah "membaratkan" sistem hukum Turki. Menurut Anderson, "Pada saat dimulainya revolusi, pemerintah Attaturk memang menyatakan akan memperlakukan undang-undang baru yang bersumber pada warisan Islam Turki, tetapi setelah berjalan beberapa bulan perbedaan pendapat di antara para anggota komite (legislatif) tidak ada habis-habisnya untuk merumuskan tujuan ini, pemerintah kehilangan kesabarannya. Pada saat yang membingungkan inilah mereka mengambil ketetapan untuk membawa negaranya ke dunia Barat, bukan kepada dunia Timur, bahwa situasinya terlalu mendesak untuk menyusun kodifikasi-kodifikasi hukum yang baru dan asli (dari Turki) sehingga mendorong pemerintah untuk secara drastik mengambil alih secara utuh peraturan-peraturan hukum Eropa". ${ }^{29}$

Meskipun sekularisasi telah diterapkan di Turki, apalagi pada 1937 telah dipemaklumkan bahwa "Turki adalah negara sekular",

28 Ibid., hlm. 98-99.

${ }^{29}$ Anderson, Hukum Islam di Dunia Moderen. hlm. 106. 
mayoritas bangsa Turki tetap yakin bahwa mereka adalah Muslim. Bahkan di kalangan para penguasa pun sebagian besar menegaskan bahwa mereka tidak menolak Islam, mereka hanya mengikuti sikap Barat, bahwa agama adalah masalah pribadi (yang mengatur hubungan) antara setiap individu dengan Tuhan; bukan sistem hukum yang harus dilaksanakan oleh negara. ${ }^{30}$

\section{Kodifikasi Hukum Islam dalam Majallah (Mecelle)}

Usaha pembentukan hukum Islam dalam sebuah undang-undang telah dimulai sejak abad ke-2 H (abad ke-8 M). saat itu Ibn Al-Muqaffa' pernah mengirim surat kepada Khalifah Al-Mansyur (mem. 137-159 H/754-775 M) untuk membuat suatu undang-undang umum yang berlaku untuk semua wilayah. Surat itu dikirimkan Ibn Al-Muqaffa' kepada Khalifah, setelah dia melihat adanya perbedaan keputusan dari hakim-hakim dalam persoalan yang sama. Akan tetapi surat tersebut tidak mendapat sambutan yang cukup pada waktu itu, karena para fuqaha tidak ingin memaksa orang lain untuk mengikuti pendapatpendapatnya.

Kemudian pada abad ke-11 H (abad ke-17 M), Sultan Muhammad Alamkir (1038-1118 H), seorang raja India, membentuk suatu panitia yang tediri dari ulama-ulama India terkemuka yang diketuai oleh Syekh Nazzan, diberi wewenang oleh Sultan untuk membuat kitab yang menghimpun riwayat-riwayat (pendapat-pendapat) yang disepakati dari mazhab Hanafi. Kitab tersebut terkenal dengan nama, "Al-Fatawa Al-Hindiyah" (fatwa-fatwa India). Meskipun pembuatan kitab tersebut bersifat resmi, namun tidak mengikat bagi hakim dalam memberikan fatwa, serta dari sistem penyusunannya tidak menggunakan sistem dalam pembuatan undang-undang, tetapi hanya merupakan kitab fiqh pada umumnya. ${ }^{31}$

Usaha nyata utnuk menempatkan ketentuan hukum Islam dalam bentuk perundang-undangan negara baru terbentuk dengan munculnya "Majallah Al-Ahkâm Al-'Adliyyah", yang kodifikasi pada masa pemerintahan Turki Utsmani yang disusun tahun 1869-1876, dalam bahas Turki disebut "Mecelle-i Ahkâm-i Adliye". Undang-undang ini telah diterjemahkan dalam edisi Indonesia, dengan judul " Kitab Undang-Undang Hukum Perdata Islam".

31 Hanafie, Pengantar dan Sejarah Hukum Islam (Jakarta: Bulan Bintang. 1977), hlm. 216-217. 
Kodifikasi hukum Majallah ini memiliki makna yang sangat penting, Pertama, karena dalam sejarah dikenal sebagai kodifikasi hukum pertama yang bersumber pada Syari'ah. Kedua, Majallah lahir dan lebih merupakan perlawanan yang berhasil terhadap kecenderungan mengadopsi hukum Eropa pada kesultanan Turki Utsmani. Materi Majallah ini diturunkan dari yurisfrudensi Hanafi, namun tidak selalu memuat pendapat fuqaha Hanafi terkemuka, sebagian pendapat yang dimasukan sebenarnya berasal dari non-Hanafi. Ketiga, Majallah melambangkan usaha pertama oleh negara Islam untuk melembagakan Syari'at, dan lebih dari itu, Majallah diberlakukan di pengadilan sekular (nizami) di seluruh kesultanan Turki Utsmani.

Keputusan untuk menyusun Majallah muncul dari perselisih-an mengenai apakah Pemerintahan Turki Utsmani harus mengadopsi perundang-undangan sipil Perancis atau tidak. Salah satu ilmuwan Islam pada masa itu, Ahmed Cevdet Pasha (1822-1895), memperjuangkan pandangan bahwa yurisfrudensi Hanafi itulah yang semestinya diadopsi. Kemudian Dewan Menteri mempercayakan penyusunan karya itu kepada sebuah komisi dan menunjuk Cevdet Pasha sebagai ketuanya. Komisi tersebut menyelesaikan enam belas buku Majallah, yang kemudian diberlakukan lewat keputusan dari Sultan. ${ }^{32}$

Majallah al-Ahkam terdiri atas 16 Buku dengan 1851 pasal, bagian pendahuluan diawali oleh dua bagian yang mendefiniskan fiqh (hukum Islam) dan komponen-komponennya, serta pernyataan tentang prinsipprinsip dasarnya (yang terdiri atas 99 kaidah fiqhiyah). Setelah itu, berturut-turut keenam belas Buku membahas tentang; (1) jual beli (albuyû); (2) sewa menyewa (al-ijârah); (3) jaminan (al-kafâlah); (4) pemindahan utang (al-hiwâlah); (5) gadai (al-rahn); (6) barang yang dipercayakan (amânâh); (7) hibah (hibah); (8) perampasan dan perusakan barang (al-ghasb wa al-itlâf); (9) pengampuan, pemaksaan, dan hak untuk membeli lebih dahulu (al-hajr, al-ikrâh wa al-syuf'ah); (10) hak milik bersama (al-syirkah); (11) perwakilan (al-wakâlah); (12) perdamaian dan pembebasan (al-sulh wa al-ibrâ); (13) pengakuan (aliqrâr); (14) gugatan (al-da'wâ); (15) pembuktian dan sumpah (albayyinât wa al-tahlîf); dan (16) putusan pengadilan dan pemeriksaan perkara (al-qadhâ).

32 Carter Vaughn Findley, "Mecelle", dalam John L. Esposito (ed.), Ensiklopedi Oxford Dunia Islam Modern, terj. Eva Y.N. dkk. (Bandung: Mizan. 2001), Jilid 4, hlm. 28. Lihat juga pengantar A. Djazuli dalam "Kitab Undang-Undang Hukum Perdata Islam", hlm. XX-XXXII. 
Pemberlakuan Majallah di Turki sendiri berlangsung sampai tahun 1926, ketika Republik Turki mengadopsi Undang-undang Sipil Swiss dan menggantikan Majallah. Sedangkan di wilayah selain Turki, Majallah berlaku di Albania sampai tahun 1928, di Libanon Majallah berlaku sampai tahun 1932, di Suriah sampai tahun 1949, di Irak pada 1953, dan Yordania sampai 1977.33

\section{Penutup}

Seperti yang sudah menjadi keharusan, bahwa setiap perubahan yang dilakukan akan membawa pergeseran sistem tata nilai, baik cepat atau lambat, besar atau kecil, moderat atau radikal, begitu pula dengan yang terjadi terjadi di Turki. Perubahan di Turki yang diawali sejak abad ke-18 telah membawa perubahan yang radikal dalam tata kehidupan dan politik di Turki. Sistem nilai Turki yang semula berdasar Syari'ah (Islam) yang telah hidup dan tumbuh selama berabad-abad tergantikan oleh sistem baru yang diadopsi dari Barat. Bahkan hapusnya kekhalifahan sebagai simbol Agama dan politik umat Islam di Turki, merupakan salah satu efek yang muncul dari sekularisasi yang dicanangkan Turki. Perubahan hukum Syari'ah dengan hukum Barat, juga merupakan upaya radikal dalam sekularisasi Turki.

Apologi apapun yang dilakukan oleh tokoh-tokoh sekularisasi Turki, tidak bisa merubah keadaan, harga yang mahal yang harus dibayar dalam sekulariasi Turki, jelas menyisakan ruang pertanyaan, tentang posisi Syari'ah Islam dalam sistem kehidupan modern, di mana Islam di yakini sebagai rahmatan lil al-'alaimin.

\section{DAFTAR PUSTAKA}

Djazuli, A. 2000. "Syari'ah Sebagai Rahmatan Li Al-Alamin". pengantar dalam Kitab Undang-Undang Hukum Perdata Islam. terj. Tajul Arifin, dkk. Bandung: Kiblat Press.

Erik J. Zurcher, Turkey A Modern History, London: I. B. Tauris, 1995.

Farhat J. Ziadeh, "Mazhab-Mazhab Hukum Sunni", dalam John L. Esposito (ed.), Ensiklopedi Oxford Dunia Islam Modern, terj. Eva Y.N. dkk. Jilid 2, Bandung: Mizan, 2001.

33 Findley, "Mecelle", dalam John L. Esposito. hlm 30. Coulson, Hukum Islam. hlm. 179; dan Schacht, Pengantar Hukum Islam. hlm. 121. 
Feroz Ahmad, "Turki", dalam John L. Esposito (ed.), Ensiklopedi Oxford Dunia Islam Modern, terj. Eva Y.N. dkk. Jilid 6, Bandung: Mizan, 2001.

Findley, Carter Vaughn. 2001. "Mecelle", dalam John L. Esposito (ed.), Ensiklopedi Oxford Dunia Islam Modern, terj. Eva Y.N. dkk. Bandung: Mizan.

Hanafie, Pengantar dan Sejarah Hukum Islam, Jakarta: Bulan Bintang, 1977.

Harun Nasution, Pembaharuan dalam Islam Sejarah Pemikiran dan Gerakan, Jakarta: Bulan Bintang, 1996.

Hassan Ibrahim Hassan, Sejarah dan Kebudayaan Islam, Yogyakarta: Kota Kembang, 1997, hlm. 324.

Ira M. Lapidus, Sejarah Sosial Ummat Islam, Jakarta: PT. RajaGrafindo Persada, 2000.

J.N.D. Anderson, Hukum Islam di Dunia Moderen, terj. Machnun Husein, Yogyakarta: Tiara Wacana Yogya, 1994.

Joseph Schacht, Pengantar Hukum Islam, terj. Moh. Said, dkk. Proyek Pembinaan Prasarana dan Sarana PTAI, Dirjen Binbaga Islam, Depag RI, 1985.

Kitab Undang-Undang Hukum Perdata Islam, terj. Tajul Arifin, dkk., Bandung: Kiblat Press, 2000.

Mukti Ali, Islam dan Sekularisasi di Turki Modern, Jakarta: Djambatan, 1994.

Noel J. Coulson, Hukum Islam dalam Perspektif Sejarah, terj. Hamid Ahmad, Jakarta: P3M, 1987.

Serip Mardin, "Tanzimat", dalam John L. Esposito (ed.), Ensiklopedi Oxford Dunia Islam Modern, terj. Eva Y.N. dkk. Jllid 5, Bandung: Mizan, 2001.

Toprak, Binnaz. 1999. Islam dan Perkembangan Politik di Turki. Yogyakarta: Tiara Wacana Yogya.

Yatim, Badri. 2001. Sejarah Peradaban Islam. Jakarta: PT. RajaGrafindo Persada. 